\title{
Palliative pelvic exenteration using iliofemoral bypass with synthetic grafts for advanced cervical carcinoma
}

\author{
İleri evre serviks kanseri için yapılan palyatif pelvik \\ egzenterasyonda sentetik greftli ilyofemoral bypass kullanılması
}

\author{
(1) Burak Tatar1, (1) Yakup Yalçın², (1) Evrim Erdemoğlu3 \\ ${ }^{1}$ University of Health Sciences, Samsun Training and Research Hospital, Clinic of Gynecologic Oncology, Samsun, Turkey \\ 2 Isparta State Hospital, Clinic of Gynecologic Oncology, Isparta, Turkey \\ 3 Suleyman Demirel University Faculty of Medicine, Department of Gynecologic Oncology, Isparta, Turkey
}

\begin{abstract}
Objective: Recurrent cervical cancer can cause severe morbidity. Despite the severe morbidity after surgery, pelvic exenteration is still used today for mainly curative intent. This intention is neither based on randomized controlled trials (RCTs) nor high quality non-RCTs with adequate patient numbers comparing medical management with surgery. The same is true for exenteration for palliative intent, so the patient selection for either curative or palliative intent must be considered on a patient-by-patient basis.

Materials and Methods: A 35-year-old patient who had undergone primary chemo-radiotherapy for advanced cervical cancer presented with intractable pain on the swollen left leg and pelvis 8 months later. Left lower extremity Doppler ultrasound revealed echogenic thrombus in the external iliac, femoral, and popliteal veins, consistent with acute deep vein thrombus. She underwent total exenteration, end colostomy, ileal urinary conduit, pelvic lymphadenectomy, paraortic lymph node sampling, and ilio-femoral arterial and venous bypass.

Results: The procedure relieved her pain, the leg diameter dramatically decreased from $75 \mathrm{~cm}$ to $44 \mathrm{~cm}$, and circulation of the leg was reestablished. The procedure deferred leg amputation for about five months.

Conclusion: To the best of our knowledge, this is the first report of a palliative pelvic exenteration for cervical cancer with combined iliofemoral arterial and venous bypasses. These procedures, with high morbidity and mortality, are also more controversial when undertaken for just palliation of symptoms. They must be considered in the basis of each patient, and the benefits and risks must be discussed thoroughly in a realistic perspective with the patient.

Keywords: Cervical cancer, iliofemoral bypass, palliation, pelvic exenteration

$\ddot{O} z$

Amaç: Nüks serviks kanseri ciddi morbiditeye neden olabilir. Cerrahi sonrası yüksek morbiditeye rağmen, pelvik egzenterasyon günümüzde temel olarak küratif amaçlı kullanılır. Bu yaklaşım, medikal tedavi ve cerrahiyi karşılaştıran randomize kontrollü çalışmalar (RCT) ya da yüksek kaliteli yeterli sayıda hastayı içeren RCT dışı çalışma temelli değildir. Aynı durum palyasyon amaçlı yapılan egzenterasyon için geçerlidir. Bu nedenle palyatif ya da küratif amaçlı yapilan egzenterasyonun hasta seçimi hasta bazlı olmalıdır.

Gereç ve Yöntemler: İleri evre serviks kanseri için daha önce primer kemo-radyoterapi almış olan 35 yaşındaki hasta, tedaviden 8 ay sonra sol bacakta şişlik ve anti enflamatuvar ilaçlarla dinmeyen ağnı şikayeti ile başvurdu. Sol alt ekstremite Doppler incelemesinde akut derin ven trombozu ile uyumlu; eksternal ilyak, femoral ve popliteal venlerde ekojenik trombüs saptandı. Hastaya total pelvik egzenterasyon, uç kolostomi, ileal üriner konduit, pelvikparaaortik lenfadenektomi ve ilio-femoral arteriyel ve venöz bypass yapıldı.

Bulgular: Operasyon hastanın ağrısını dindirdi, bacak çapı 75 cm'den 44 cm'ye dramatik olarak geriledi ve bacaktaki dolaşım yeniden sağlandı. Bu operasyon, bacak ampütasyonunu 5 ay öteledi.

Sonuç: Bildiğimiz kadarı ile bu olgu sunumu, kombine ilio-femoral arteryel ve venöz bypass içeren ilk palyatif egzenterasyon sunumudur. Bu tip bir cerrahi işlemin yüksek morbidite ve mortalitesi vardır. Özellikle sadece palyasyon amaçlı kullanımı tartışmalıdır ve hasta bazlı tartışılmalıdır. İşlemin risk ve faydaları gerçekçi bir perspektifte hasta ile paylaşılmalıdır.

Anahtar Kelimeler: Serviks kanseri, iliofemoral bypass, palyasyon, pelvik egzenterasyon
\end{abstract}

Address for Correspondence/Yazışma Adresi: Burak Tatar

University of Health Sciences, Samsun Training and Research Hospital, Clinic of Gynecologic Oncology, Samsun, Turkey

Phone: +90 5333479571 E-mail: buraktatar@yahoo.com ORCID ID: orcid.org/0000-0002-6495-0174

Received/Geliș Tarihi: 22.09.2018 Accepted/Kabul Tarihi: 24.11.2018

${ }^{\oplus}$ Copyright 2019 by Turkish Society of Obstetrics and Gynecology

Turkish Journal of Obstetrics and Gynecology published by Galenos Publishing House 


\section{Introduction}

It is estimated that there are 527.600 new cervical cancer cases every year, nearly 265.700 deaths attributable to this malignancy, and most of the cases are seen in developing countries $^{(1)}$. Most patients present at advanced stages and more than half of all patients with cervical cancer receive radiotherapy during the course of their treatment. Nearly onethird of patients who receive radiotherapy at any stage (stage I to stage IV) will have local or distant failure ${ }^{(2)}$. Recurrence after radiotherapy is maybe one of the most challenging situations in gynecologic oncology for patients with cervical cancer.

Recurrent or advanced cervical cancer can cause severe morbidity including intractable pain, continuous foulsmelling discharge, fecal and urinary incontinence due to fistula formation, vaginal bleeding, intestinal or ureteric obstruction related symptoms, and sepsis. In 1948, Brunshwig( ${ }^{(3)}$ defined pelvic exenteration as, "a one-stage abdominoperineal operation with end colostomy and bilateral ureteral implantation into the colon above the colostomy," to alleviate these symptoms for 22 patients. The perioperative mortality rate was $23 \%$. Despite it having palliative intent when it was first defined, with the improvements in the surgical technique, especially with the use of modern urinary conduit technics, it has rather become a surgery for curative intent with much lower mortality rates ${ }^{(4,5)}$.

\section{Case Report}

A 35-year-old patient previously underwent primary chemoradiotherapy for a bulky [magnetic resonance imaging (MRI) revealed a mass of $70 \times 65 \times 35 \mathrm{~mm}$ ] non-keratinizing squamous cell cervical carcinoma with invasion to the proximal one-third of the vagina and parametria, and a 50x30 $\mathrm{mm}$ lymph node chain, probably metastatic, on the left iliac chain according to MRI. She presented with intractable pain in the left leg and pelvis 8 months later.

Her left leg was $75 \mathrm{~cm}$ in diameter, whereas its right counterpart was $40 \mathrm{~cm}$ at its maximum (Figure 1). Left lower extremity Doppler ultrasound revealed echogenic thrombus in the external iliac, femoral, and popliteal veins, consistent with acute deep vein thrombus.

She was discussed in an oncology round, consulted by the cardiovascular surgery department, and the risks of the operation were discussed thoroughly, explaining no possible survival benefit, extreme risk of morbidity and mortality, and that the procedure would performed only for the possible alleviation of symptoms. She was fully cooperating and demanded the surgical intervention. The surgery was undertaken as total exenteration, end colostomy, ileal urinary conduit, pelvic lymphadenectomy, paraaortic lymph node sampling, and iliofemoral arterial and iliofemoral venous bypass. Intraoperatively, the tumor was visualized infiltrating the left external and internal iliac artery, left external and internal iliac vein, recto-sigmoid, bladder, and left ureter. The left ureter was seen as hydropic. In order to remove the tumor, the external and internal iliac artery, vein, and ureter were cut (Figure 2). With the help of an inguinal incision, the femoral artery and vein were identified, dissected, and cut. The backflow from the common femoral artery was confirmed and ilio-femoral arterial bypass was completed using an $8 \mathrm{~mm}$ ringed polytetrafluoroethylene (PTFE) graft. The thrombi in the femoral vein were cleared, and after the blood flow from the common femoral vein was confirmed, the femoro-iliac venous bypass was completed using a 10mm PTFE graft (Figure 3). The flow from the distal part of the artery and back from the vein was confirmed. The right internal iliac artery was ligated and cut. The left presacral area was dissected and the sciatic nerve was preserved. The tumor was removed by stripping the pubis and ilium. After completing the exenteration and conduit, a prolene mesh was used to reconstruct the cut inguinal ligament.

The patient was discharged from hospital three weeks after the procedure, as her leg diameter dramatically decreased from $75 \mathrm{~cm}$ to $44 \mathrm{~cm}$. The circulation of the leg was re-established

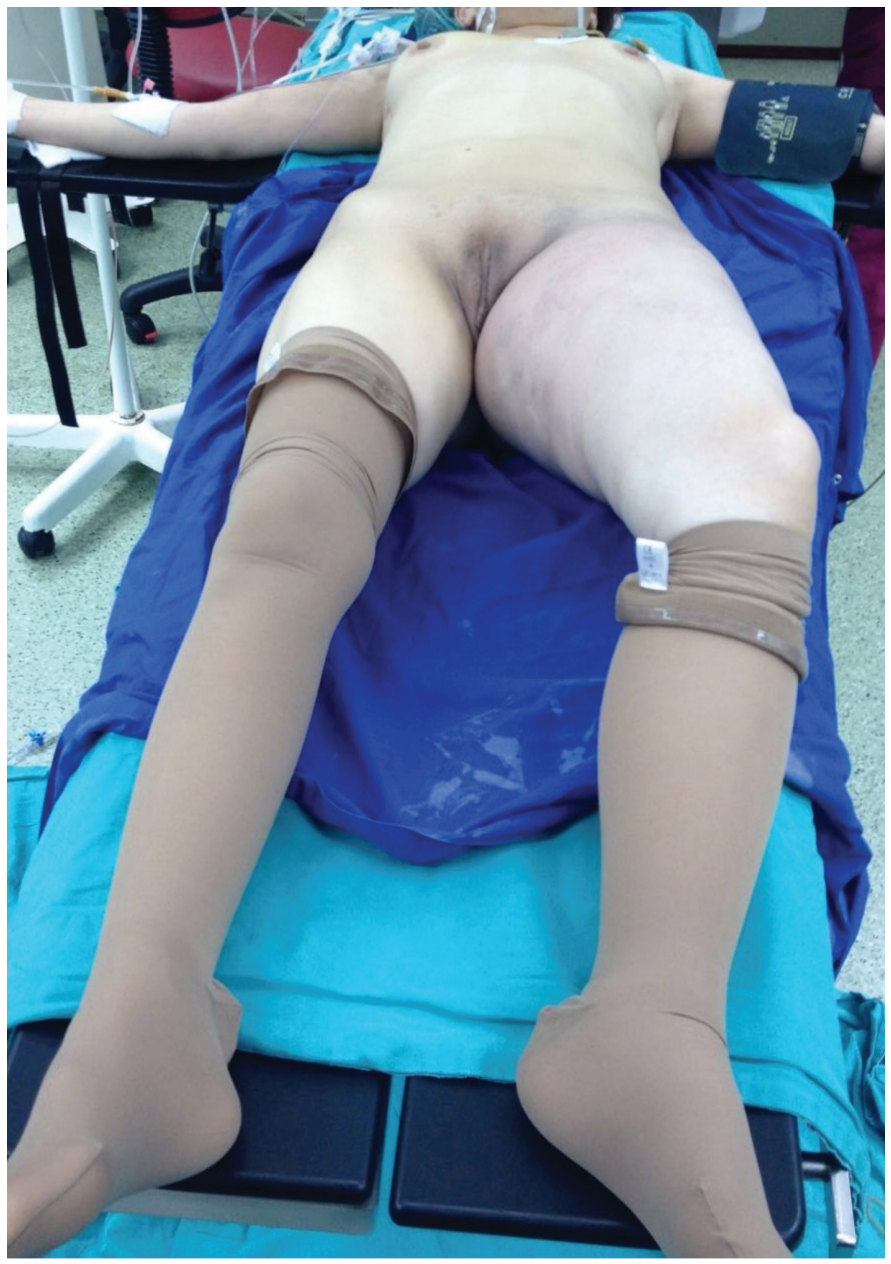

Figure 1. The image of the patient just before the procedure. Swollen left lower extremity is clearly seen 


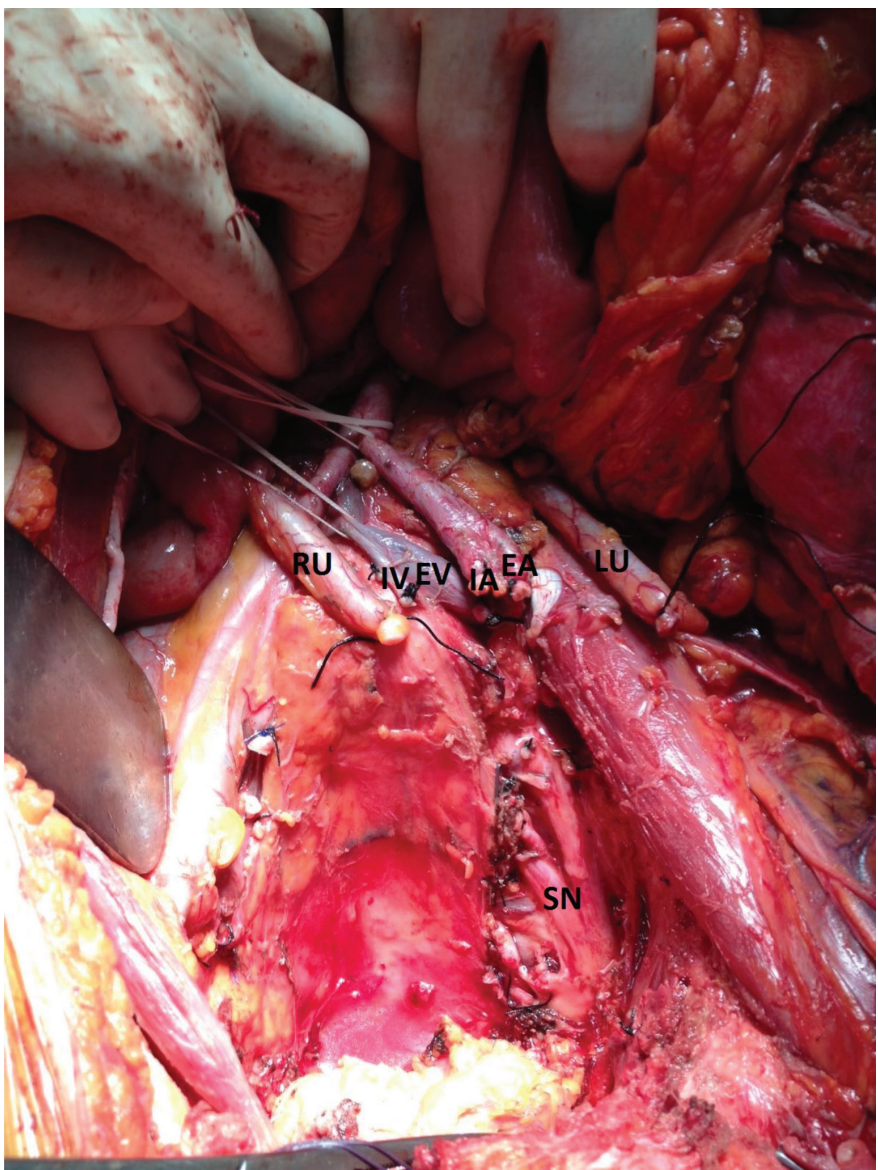

Figure 2. Before the reconstruction phase; operative field after total pelvic exenteration and left external iliac vessels ligated

RU: Right ureter, IV: Internal iliac vein, EV: External iliac vein, IA: Internal iliac artery, EA: External iliac artery, LU: Left ureter, SN: Sacral nerve roots

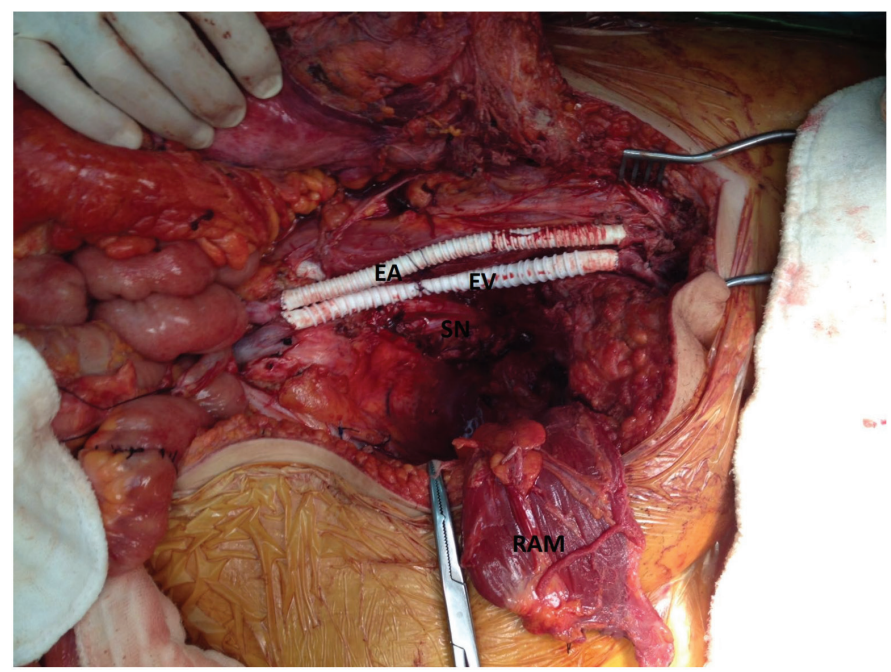

Figure 3. Operative field after iliofemoral arterial bypass and femoro-iliac venous bypass with polytetrafluoroethylene grafts EA: External iliac artery, EV: External iliac vein, SN: Sacral nerve roots, RAM: Rectus abdominis muscle before flap reconstruction and amputation was delayed until five months later when she was admitted to hospital for ischemic changes in her left foot and pain. The patient died of sepsis, approximately eight months after the palliative surgery.

\section{Discussion}

After the initial description of pelvic exenteration by Brunshwig in 1948, there has been much debate about the surgery despite the refinement of the technique, especially for urinary conduits. The debate is about its indications, patient selection criteria, the technique, its aim, and its necessity. According to some articles after the 2000's, survival after palliative pelvic exenteration is between $10.5 \%$ for 2 years to $27 \%$ for 5 years, whereas the reports from same authors indicate a 5-year survival between $50 \%$ and $60 \%$ if the exenteration is performed with curative intent ${ }^{(4,6)}$.

There is a more recent palliative pelvic exenteration series of 13 patients from Brazil, 9 of which were performed for recurrent cervical cancer. The 2-year overall survival was $15.4 \%$ and only 6 of 13 patients survived more than 5 months ${ }^{(7)}$.There is also a controversy about the definition of palliative pelvic exenteration. An early publication of Deckers et al. ${ }^{(8)}$ defined pelvic exenteration as an efficient way to alleviate symptoms such as pain, fistulas, pelvic sepsis, hemorrhage, and malodorous discharge. Nevertheless, there is controversy about the definition of palliative pelvic exenteration. From the above-mentioned authors, Marnitz et al. ${ }^{(4)}$ explained that the difference between palliative and curative exenterations could be discriminated by the resection margin status. Finlayson and Eisenberg emphasized three definitions of palliative exenteration in their review ${ }^{(9)}$. First, based on the intent that the objective is just for palliation of symptoms. Second, for patients who undergo surgery for curative intent but intraoperatively macroscopic tumor is left behind because of the non-resectability of the tumor. The third definition they found in the literature is that all surgical effort for failed primary curative effort including radiation, surgery or chemotherapy, which may be combined with each other. In the review of Hope and Pothuri ${ }^{(10)}$, they mentioned that palliative exenteration surgery was accomplished to alleviate discomfort and not necessarily in an attempt to prolong life. They also stressed that the literature for palliative pelvic exenteration was not homogenous in the tumor, patient, and surgical intervention basis, making it difficult to compare. This problem was also documented in a recent Cochrane review for all exenteration procedures ${ }^{(11)}$.

In our case, because the tumor was in close proximity of the sacral plexus, the treatment was planned with palliative intent, not curative. Intraoperatively, the tumor was stripped from the nerve plexus. This region is the boundary between curative intent of laterally extended endopelvic resection as described by Höckel ${ }^{(12)}$ and palliative surgery. 
There is a controversy over all kinds of pelvic exenterations for gynecologic malignancies; their indications are not clear, the surgical procedures are not uniform, and most importantly, their efficacy over non-surgical treatments are not proven. Chemotherapy may be an alternative for palliation of symptoms to surgery, but there are no randomized controlled trials comparing one with the other in the literature. Full recovery, if possible, from a palliative exenteration may take about 4-5 months, survival may not be much more and quality of life during this period is poor.

There is a case series from Memorial Sloan Kettering Cancer Center; 11 patients with recurrent uterine cancer and 3 with recurrent cervical cancer underwent pelvic exenteration for curative intent. Two of the patients had femoral-femoral arterial bypass procedures. The specific survival and prognosis of these two patients is not mentioned ${ }^{(13)}$.

A recent report from Romania described palliative posterior pelvic exenteration with partial cystectomy for a tumor invading the sciatic foramen for fistula after a previous radical hysterectomy ${ }^{(14)}$. No detail was included regarding the prognosis or survival of the patient in the article.

To the best of our knowledge, this is the first report of a palliative pelvic exenteration for cervical cancer with combined iliofemoral arterial and venous bypasses.

Under these circumstances, such procedures with high morbidity and mortality are also more controversial when undertaken simply for palliation of symptoms. They must be considered on a patient-by-patient basis, and the benefits and risks must be discussed thoroughly in a realistic perspective, taking into account the physical and emotional aspects of the patient before planning the procedure.

\section{Ethics}

Informed Consent: It was obtained.

Peer-review: External and internal peer-reviewed.

\section{Authorship Contributions}

Surgical and Medical Practices: E.E., Y.Y., B.T., Concept: E.E., B.T., Design: Y.Y., Data Collection or Processing: B.T., Y.Y., Analysis or Interpretation: B.T., Literature Search: B.T., E.E., Writing: B.T.

Conflict of Interest: No conflict of interest was declared by the authors.

Financial Disclosure: The authors declared that this study received no financial support.

\section{References}

1. Torre LA, Bray F, Siegel RL, Ferlay J, Lortet-Tieulent J, Jemal A. Global cancer statistics, 2012. CA: a cancer journal for clinicians 2015;65:87-108.

2. Hong JH, Tsai CS, Lai CH, Chang TC, Wang CC, Chou HH, et al. Recurrent squamous cell carcinoma of cervix after definitive radiotherapy. International journal of radiation oncology, biology, physics 2004;60:249-57.

3. Brunschwig A. Complete excision of pelvic viscera for advanced carcinoma; a one-stage abdominoperineal operation with end colostomy and bilateral ureteral implantation into the colon above the colostomy. Cancer 1948;1:177-83.

4. Marnitz S, Kohler C, Muller M, Behrens K, Hasenbein K, Schneider A. Indications for primary and secondary exenterations in patients with cervical cancer. Gynecologic oncology 2006;103:1023-30.

5. Berek JS, Howe C, Lagasse LD, Hacker NF. Pelvic exenteration for recurrent gynecologic malignancy: survival and morbidity analysis of the 45-year experience at UCLA. Gynecologic oncology 2005;99:153-9.

6. Lambrou NC, Pearson JM, Averette HE. Pelvic exenteration of gynecologic malignancy: indications, and technical and reconstructive considerations. Surgical oncology clinics of North America 2005;14:289-300.

7. Guimaraes GC, Baiocchi G, Ferreira FO, Kumagai LY, Fallopa CC, Aguiar S, et al. Palliative pelvic exenteration for patients with gynecological malignancies. Archives of gynecology and obstetrics 2011;283:1107-12.

8. Deckers PJ, Olsson C, Williams LA, Mozden PJ. Pelvic exenteration as palliation of malignant disease. American journal of surgery 1976;131:509-15.

9. Finlayson CA, Eisenberg BL. Palliative pelvic exenteration: patient selection and results. Oncology (Williston Park) 1996;10:479-84; discussion 84-6, 90, 93

10. Hope JM, Pothuri B. The role of palliative surgery in gynecologic cancer cases. The oncologist 2013;18:73-9.

11. Ang C, Bryant A, Barton DP, Pomel C, Naik R. Exenterative surgery for recurrent gynecological malignancies. The Cochrane database of systematic reviews 2014;2:CD010449.

12. Hockel M. Laterally extended endopelvic resection. Novel surgical treatment of locally recurrent cervical carcinoma involving the pelvic side wall. Gynecologic oncology 2003;91:369-77.

13. Caceres A, Mourton SM, Bochner BH, Gerst SR, Liu L, Alektiar KM, et al. Extended pelvic resections for recurrent uterine and cervical cancer: out-of-the-box surgery. International journal of gynecological cancer : official journal of the International Gynecological Cancer Society 2008; 18:1139-44.

14. Bacalbasa N, Balescu I. Palliative Pelvic Exenteration for Pelvic Recurrence Invading the Sciatic Foramen with Chronic Cutaneous Perineal Fistula after Radical Surgery for Cervical Cancer: A Case Report. Anticancer research 2015;35:4877-80. 